\title{
Additional notes on the diet of Japalura swinhonis (Agamidae) from southwestern Taiwan, with comments about its dietary overlap with the sympatric Anolis sagrei (Polychrotidae)
}

\author{
Gerrut Norval ${ }^{1,}$, Shao-Chang Huang ${ }^{2}$, Jean-Jay $\mathrm{Mao}^{3}$, Stephen R. Goldberg', Kerry Slater ${ }^{1}$ \\ ${ }^{1}$ Applied Behavioural Ecology \& Ecosystem Research Unit, Department of Environmental Sciences, University of South Africa, \\ Republic of South Africa. \\ ${ }_{2}^{2}$ Queensland Brain Institute, The University of Queensland, St. Lucia, Queensland, Australia. \\ ${ }^{3}$ Department of Forestry \& Natural Resources, National Ilan University, Ilan, Taiwan, R.O.C. \\ ${ }^{4}$ Department of Biology, Whittier College, Whittier, California, USA. \\ * Correspondence: Global Village Organization, 577 Chong San Road, Chiayi City, 600, Taiwan, R.O.C. Phone: +88652869310 , Fax: +886 \\ 5227 9967, E-mail: gnorval@gmail.com
}

Received: 9 September 2012; received in revised form: 28 October 2012; accepted: 31 October 2012.

Japalura swinhonis is an endemic agamid lizard in Taiwan, and although its diet has been examined in northern Taiwan and Orchid Island, it has not been investigated in other parts of its range. Investigating the diet of a species from different parts of its range is crucial due to temporal and spatial variations in it. This study examined the dietary items of $47 \mathrm{~J}$. swinhonis from Santzepu and Yunlin, southwestern Taiwan. We also reviewed the diet of $J$. swinhonis and compared it with that of Anolis sagrei from Santzepu, where these species are sympatric in anthropogenically created habitats such as Areca catechu plantations and fruit orchards. The diet of J. swinhonis from Santzepu was dominated by hymenopterans, followed by coleopterans, lepidopterans and trichopterans, while that of the J. swinhonis from Yunlin was dominated by isopterans, followed by hymenopterans, lepidopterans and coleopterans. The diet of $A$. sagrei from Santzepu was mainly dominated by hymenopterans, lepidopterans, araneids, hemipterans, coleopterans, dipterans, isopterans and orthopterans, in that order of frequency. From the results of this study it is evident that in areas where J. swinhonis and A. sagrei are sympatric there is a substantial dietary niche overlap, and competition for prey is very likely.

Key words: arboreal; competition; invasive species; sit-and-wait forager.

Notas adicionales sobre la dieta de Japalura swinhonis (Agamidae) en el suroeste de Taiwán, con comentarios acerca de su solapamiento trófico con la especie simpátrica Anolis sagrei (Polychrotidae). Japalura swinhonis es un agámido endémico en Taiwán, y aunque su dieta se ha examinado en el norte de Taiwán y la isla de Orchid, no se ha estudiado en otras partes de su rango de distribución. Investigar la dieta de una especie en diferentes partes de su rango geográfico es crucial debido a la existencia de variaciones temporales y espaciales. Este estudio examina la dieta de 47 J. swinhonis de Santzepu y Yunlin, en el suroeste de Taiwan. También revisamos la dieta de J. swinhonis y la comparamos con la de Anolis sagrei en Santzepu, donde estas especies aparecen en simpatría en hábitats creados por el hombre, tales como las plantaciones de Areca catechu y frutales. La dieta de J. swinhonis de Santzepu estuvo dominada por himenópteros, seguidos de coleópteros, lepidópteros y tricópteros, mientras que la de J. swinhonis de Yunlin estuvo dominada por isópteros, seguidos de himenópteros, lepidópteros y coleópteros. La dieta de $A$. sagrei de Santzepu consistió principalmente de himenópteros, lepidópteros, araneidos, hemípteros, coleópteros, dípteros, isópteros y ortópteros, en este orden de frecuencia. A partir de los resultados de este estudio parece evidente que en áreas en las que J. swinhonis y A. sagrei aparecen en simpatría existe un solapamiento sustancial de la dieta, con una probable competencia por las presas.

Key words: arbórea; competencia; especies invasoras; predador sit-and-wait. 
A crucial part of the natural history of an animal is its diet, because not only does it reveal the source of the animal's energy for growth, maintenance, and/or reproduction (DUNHAM et al., 1989; ZUG et al., 2001), but it also provides information on the ecological roles of the animal. Diets are thus often used in intraspecific (e.g. ROCHA \& ANJOS, 2007; Bulté et al., 2008) and interspecific (e.g. Ortega-Rubio et al., 1995; VieIRA \& PORT, 2007) niche-overlap studies. Since there may be temporal and spatial variations in the diet of a species (e.g. RodríGUEZ et al., 2008; HaWlena \& PÉrez-MEllado, 2009; GOODYEAR \& PIANKA, 2011), information on diet from different localities is useful in elucidating the ecological niche of an animal.

The Swinhoe's tree lizard (Japalura swinhonis Günther, 1864) is an endemic agamid lizard in Taiwan and occurs throughout the island, and on the offshore Orchid Island at elevations below $1500 \mathrm{~m}$ (ОтА, 1991). It is diurnal and occurs in various habitat types, ranging from forests to areas extensively altered by anthropogenic activities, provided there is sufficient sunlight (KUO et al., 2007). Dietary descriptions have only been made for J. swinhonis from northern Taiwan (KUO et al., 2007) and Orchid Island (HuANG, 2007). There is thus still a need for dietary descriptions from other parts of its range.

The brown anole (Anolis sagrei Duméril \& Bibron, 1837), also known as Norops sagrei (KÖHLER, 2000; LEE, 2000), is an exotic invasive lizard species in Taiwan (Norval et al., 2002, 2009; ChANG, 2007). It is a diurnal trunk-ground species that favours a variety of sunny habitat types and areas disturbed by anthropogenic activities (SCHWARTZ \& Henderson, 1991). Anolis sagrei is an aggres- sive competitor that has been shown to displace other species of lizards from their habitats (SAlzBurG, 1984; TOKARZ \& BeCK, 1987; Losos et al., 1993; Losos \& SPILLER, 1999). Ongoing research on this species in Taiwan indicates that in areas disturbed by anthropogenic activities, it is increasingly becoming part of local ecosystems, both as predator (HUANG et al., 2008a; NORVAL et al., 2010) and prey (NorVAL et al., 2004, 2007, 2011; Norval \& MAO, 2008; CHIU et al., 2011).

This study aims to identify the dietary items of $J$. swinhonis, using individuals that were collected on an ad hoc basis from southwestern Taiwan, to contribute to the overall understanding of the diet of this species. Furthermore, the current knowledge on the diet of $J$. swinhonis is reviewed and compared with that of $A$. sagrei from Taiwan.

\section{Materials AND MeTHOdS}

On the $28^{\text {th }}$ of June, 2002, a J. swinhonis male was found dead on a road (DOR) in Santzepu, Sheishan District, Chiayi County, southwestern Taiwan (23 25' 46" N, 120' 28' 55" E; datum WGS84). During July and September 2004, and on the $5^{\text {th }}$ of October, 2007, live J. swinhonis were also collected from a small betel nut palm (Areca catechu L.) plantation in Santzepu (23 25' 42" N, 120' 29' 06" $\mathrm{E}$; datum WGS84), where J. swinhonis is sympatric with $A$. sagrei. Between the $24^{\text {th }}$ of May and the $1^{\text {st }}$ of June, 2008, additional specimens were collected from two localities (230 $36^{\prime} 34^{\prime \prime} \mathrm{N}$, $120^{\circ} 34^{\prime} 13^{\prime \prime} \mathrm{E}$ and 23 35' 44" N, 120'35' 47" E) in Yunlin County, southwestern Taiwan.

The snout-vent length (SVL) and tail length (TL) were measured to the nearest $\mathrm{mm}$ with a transparent plastic ruler, and the ani- 
mals were weighed (body mass) to the nearest $0.1 \mathrm{~g}$ with a digital scale. The DOR lizard was dissected by making a mid-ventral incision and the stomach was removed and slit longitudinally, after which the stomach contents were removed. In order to determine the diet of the living $J$. swinhonis in a non-lethal manner in the field, the mouth of each collected individual was held open by placing a hard plastic tube $($ diameter $=10 \mathrm{~mm}$; length $=30 \mathrm{~mm}$ ) in the oral cavity of the lizard when it opened its mouth as a threat display in response to handling. The stomach contents were then obtained by inserting a no. 4 catheter, lubricated with sunflower cooking oil, into the throat

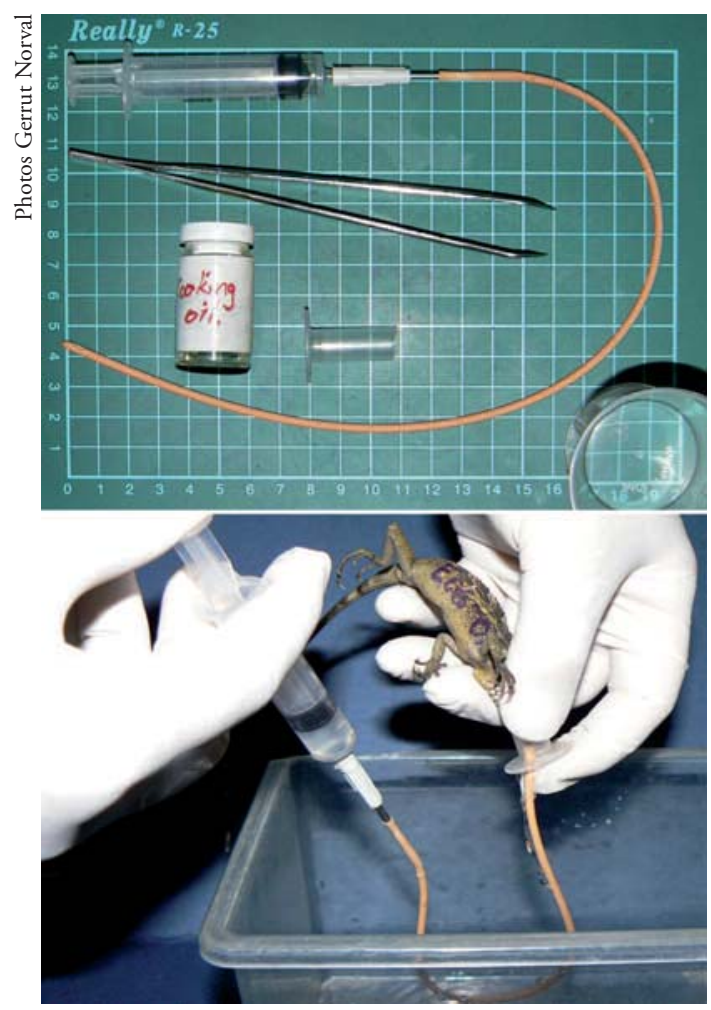

Figure 1: Stomach flushing methodology. (top) Equipment used for performing stomach flushing. (bottom) A Japalura swinhonis male undergoing stomach flushing. and stomach of the lizard, and then flushing the stomach contents out by holding the lizard facing downwards over a plastic container while injecting $15 \mathrm{ml}$ clean drinking water through the catheter into the stomach (Fig. 1). A similar method was employed by KUO et al. (2007), and in a preliminary study we found that typically more than $80 \%$ (often nearly $100 \%$ ) of the stomach contents were flushed from the stomachs of the lizards (S.C. Huang \& G. Norval, unpublished data), so we considered the method reliable enough for our investigation. After the lizards were stomach-flushed they were released back into the wild at the same locality where they had been collected.

In the laboratory, the stomach contents were spread in a petri dish and examined under a dissection microscope, and all the prey items were identified to the order level (samples from the year 2004) and, if possible, to the family level (samples from years other than 2004).

The dietary descriptions for $J$. swinhonis from Orchid Island (HuANG, 2007), and northern (KUO et al., 2007) and southwestern (this study) Taiwan were incorporated for comparison with the dietary descriptions for A. sagrei from Santzepu, southwestern Taiwan (HuANG et al., 2008a; Norval et al., 2010). Because not all the dietary items were identified to the family level, the order level was used in the analysis as the resource category. We used the software Ecological Methodology Version 6.1.1. (Exeter software, Setauket, New York, USA) to analyze and compare the diets of $J$. swinhonis and $A$. sagrei as follows. The diet diversity index of each species was measured with the Shannon-Wiener function, using the original $\left(\mathrm{H}^{\prime}\right)$ and the natural logarithm-transformed $\left(\mathrm{N}_{1}\right)$ indexes; however, since HUANG (2007) and KUO et al. (2007) did 
not indicate the numbers of prey items, the results from their studies were not used for the diet diversity index calculations. Niche breadths of $J$. swinhonis and $A$. sagrei were estimated using the Levin's measure of niche breadth (B) and the Levin's standardized niche breadth $\left(B_{A}\right)$ (KREBS, 1999). Only studies indicating the numbers of lizards that preyed on each prey type (i.e. frequency of occurrence: F) were used for these analyses, being therefore excluded the results of HUANG et al. (2008a) and part of the results described herein. The dietary niche overlap was measured with the Pianka's measure, and the percentage overlap (Schoener Overlap Index) was used to examine the extent of the dietary niche overlap (KREBS, 1999). Again, due to a lack of the required information, the results of the studies by HUANG (2007) and KUO et al. (2007) were excluded from the analysis of dietary niche overlap.

\section{RESUlTS}

Thirty-nine J. swinhonis (20 males and 19 females) were collected from Santzepu (Table 1), with SVL ranging from 51 to $77 \mathrm{~mm}$ (mean \pm
$\mathrm{SD}=65.6 \pm 7.0)$, TL from 123 to $196 \mathrm{~mm}$ (mean $\pm \mathrm{SD}=160.5 \pm 21.0)$, and body mass from 3.9 to $13 \mathrm{~g}$ (mean $\pm \mathrm{SD}=7.7 \pm 2.6$ ). Eight J. swinhonis (seven males and one female) were collected from Yunlin (Table 1), with SVL ranging from 68 to $78 \mathrm{~mm}$ (mean \pm $\mathrm{SD}=73.0 \pm 3.2$ ), TL from 168 to $202 \mathrm{~mm}$ (mean $\pm \mathrm{SD}=183.4 \pm 9.8)$, and body mass from 8.7 to $14.9 \mathrm{~g}($ mean $\pm \mathrm{SD}=11.0 \pm 1.9)$.

For description and analysis, we pooled all the dietary data of both sexes from each locality. We recorded 1277 prey items, belonging to 13 orders from three classes, from the Santzepu individuals, and 47 prey items, belonging to six orders from two classes, from the Yunlin ones (Table 2). In the stomachs of the J. swinhonis from Santzepu, the most numerous prey items were hymenopterans, more than 90\% of which were ants (Formicidae), followed by coleopterans, lepidopterans and trichopterans, respectively (Table 2). For the J. swinhonis from Yunlin, the most numerous prey items were termites (Isoptera), followed by hymenopterans (all Formicidae), lepidopterans (all caterpillars) and coleopterans, respectively (Table 2). Cumulatively, the most numerous prey items in the diet of $J$. swinhonis from southwestern

Table 1: Range and mean ( \pm SD) snout-vent length (SVL), tail length (TL) and body mass of the Japalura swinhonis from Santzepu and Yunlin used in this study.

\begin{tabular}{|c|c|c|c|c|c|c|}
\hline Locality & Collection period & Sex & $\mathrm{N}$ & SVL (mm) & $\mathrm{TL}(\mathrm{mm})$ & Mass (g) \\
\hline \multirow[t]{6}{*}{ Santzepu } & 2002 & $\hat{0}$ & 1 & 72 & 178 & 8.7 \\
\hline & 2004 & $\hat{0}$ & 18 & $58-77$ & $148-196$ & 5.9-13 \\
\hline & & & & $(70.4 \pm 4.6)$ & $(177.8 \pm 15.0)$ & $(9.7 \pm 2.2)$ \\
\hline & & q & 19 & $51-73$ & $129-167$ & $3.9-9.3$ \\
\hline & & & & $(61.4 \pm 5.6)$ & $(146.0 \pm 6.0)$ & $(6.0 \pm 1.2)$ \\
\hline & 2007 & $\widehat{0}$ & 1 & 54 & 123 & 4.2 \\
\hline \multirow[t]{2}{*}{ Yunlin } & 2008 & $\widehat{0}$ & 7 & $\begin{array}{c}68-78 \\
(73.4+3.2)\end{array}$ & $\begin{array}{c}168-202 \\
(184.3 \pm 10.2)\end{array}$ & $\begin{array}{c}8.7-14.9 \\
(11.1 \pm 2.0)\end{array}$ \\
\hline & & 우 & 1 & 70 & 177 & 10.1 \\
\hline
\end{tabular}


Table 2: Percentage of each type of dietary item (\% items) in Japalura swinhonis from two sites in southwestern Taiwan, and cumulated values considering both sites altogether. For the Yunlin population, the occurrence frequency $(\mathrm{F})$ of each prey is also shown.

\begin{tabular}{|c|c|c|c|c|c|}
\hline \multirow{3}{*}{ Class } & \multirow{3}{*}{ Order } & \multirow{3}{*}{$\begin{array}{c}\text { Santzepu } \\
\% \text { items } \\
(\mathrm{N}=1277)\end{array}$} & \multicolumn{2}{|c|}{ Yunlin } & \multirow{3}{*}{$\begin{array}{c}\text { Cumulated } \\
\% \text { items } \\
(\mathrm{N}=1324)\end{array}$} \\
\hline & & & $\%$ items & $\mathrm{F}$ & \\
\hline & & & $(\mathrm{N}=47)$ & $(\mathrm{N}=8)$ & \\
\hline \multirow[t]{11}{*}{ Insecta } & Blattaria & 0.31 & 0.00 & 0 & 0.30 \\
\hline & Coleoptera & 1.88 & 4.26 & 2 & 3.25 \\
\hline & Dermaptera & 0.08 & 0.00 & 0 & 0.08 \\
\hline & Diptera & 0.63 & 0.00 & 0 & 0.60 \\
\hline & Hemiptera & 0.71 & 0.00 & 0 & 0.68 \\
\hline & Hymenoptera & 93.50 & 14.89 & 3 & 90.71 \\
\hline & Isoptera & 0.08 & 59.57 & 4 & 2.19 \\
\hline & Lepidoptera & 1.18 & 12.77 & 5 & 1.59 \\
\hline & Orthoptera & 0.08 & 2.13 & 1 & 0.15 \\
\hline & Phasmatodea & 0.08 & 0.00 & 0 & 0.08 \\
\hline & Trichoptera & 1.10 & 0.00 & 0 & 1.06 \\
\hline Arachnida & Aranea & 0.31 & 0.00 & 0 & 0.30 \\
\hline Crustacea & Isopoda & 0.00 & 2.13 & 1 & 0.08 \\
\hline Magnoliopsida & Asterales & 0.08 & 0.00 & 0 & 0.08 \\
\hline Unknown & & 0.00 & 4.26 & 2 & 0.15 \\
\hline
\end{tabular}

Taiwan were hymenopterans (primarily Formicidae), followed by coleopterans, isopterans, lepidopterans and trichopterans, in that order of frequency (Table 2), while the prey items from the remaining orders made up ca. $3 \%$.

The diet of $A$. sagrei from Taiwan (based on the studies done in Santzepu), consisted mostly of hymenopterans (primarily Formicidae), followed by lepidopterans, araneids, hemipterans, coleopterans, dipterans, isopterans and orthopterans, respectively (Table 3). Prey items from the remaining orders made up ca. $5 \%$ of the diet of $A$. sagrei from Taiwan.

The Shannon-Wiener function resulted in $\mathrm{H}^{\prime}=0.7135\left(\mathrm{~N}_{1}=0.6099\right)$ for $J$. swinhonis and $\mathrm{H}^{\prime}=2.6238\left(\mathrm{~N}_{1}=0.1622\right)$ for A. sagrei. Niche breadth measures were $\mathrm{B}=0.6644$ and $\mathrm{B}_{\mathrm{A}}=0.0129$ for J. swinhonis, and $\mathrm{B}=1.6149$ and $\mathrm{B}_{\mathrm{A}}=0.0237$ for $A$. sagrei. The Pianka's measure and the percentage dietary niche overlap between J. swinhonis and A. sagrei were 0.945 and $65.7 \%$, respectively.

\section{DisCUSSION}

Based on what is understood about the diet of $J$. swinhonis (HUANG, 2007; KUO et al., 2007), this species can be regarded as a dietary generalist, preying upon a variety of prey types although, according to the calculated Shannon-Wiener function and Levin's measures, depending to a large extent on large numbers of a relatively few prey types. The occurrence in the diet of J. swinhonis of prey primarily active, mobile, moving on the surface, and visually conspicuous (e.g. ants, termites, and lepidopterans and their larvae) suggests that this species is an opportunistic sit-and-wait (ambush) foraging species (HueY \& PIANKA, 1981; 
Table 3: Percentage of each type of dietary item (\% items) in Anolis sagrei from Santzepu, southwestern Taiwan, according to the studies of HUANG et al. (2008a) and NORVAL et al. (2010), and cumulated values considering both studies altogether. Using the data from NoRVAL et al. (2010), the occurrence frequency (F) of each prey is calculated.

\begin{tabular}{|c|c|c|c|c|c|}
\hline \multirow{3}{*}{ Class } & \multirow{3}{*}{ Order } & \multirow{3}{*}{$\begin{array}{l}\text { HUANG et al. (2008a) } \\
\qquad \% \text { items } \\
(\mathrm{N}=2355)\end{array}$} & \multicolumn{2}{|c|}{ NORVAL et al. (2010) } & \multirow{3}{*}{$\begin{array}{c}\text { Cumulated } \\
\% \text { items } \\
(\mathrm{N}=5339)\end{array}$} \\
\hline & & & $\%$ items & $\mathrm{F}$ & \\
\hline & & & $(\mathrm{N}=2984)$ & $(\mathrm{N}=502)$ & \\
\hline \multirow[t]{18}{*}{ Insecta } & Blattaria & 0.72 & 0.50 & 13 & 0.60 \\
\hline & Coleoptera & 5.99 & 6.94 & 113 & 6.52 \\
\hline & Collembola & 0.17 & 0.34 & 7 & 0.26 \\
\hline & Dermaptera & 0.04 & 0.24 & 6 & 0.15 \\
\hline & Diptera & 3.65 & 7.86 & 101 & 6.01 \\
\hline & Hemiptera & 4.76 & 4.26 & 100 & 4.48 \\
\hline & Homoptera & 2.72 & 2.01 & 50 & 2.32 \\
\hline & Hymenoptera & 49.51 & 49.93 & 260 & 49.75 \\
\hline & Isoptera & 1.66 & 3.02 & 25 & 2.42 \\
\hline & Lepidoptera & 20.72 & 6.10 & 140 & 12.55 \\
\hline & Mantodea & 0.04 & 0.00 & 0 & 0.02 \\
\hline & Neuroptera & 0.76 & 0.24 & 7 & 0.47 \\
\hline & Odonata & 0.00 & 0.27 & 6 & 0.15 \\
\hline & Orthoptera & 0.47 & 2.68 & 67 & 1.70 \\
\hline & Plecoptera & 0.00 & 0.24 & 7 & 0.13 \\
\hline & Psocoptera & 0.89 & 0.03 & 1 & 0.41 \\
\hline & Thysanoptera & 0.09 & 0.10 & 3 & 0.09 \\
\hline & Trichoptera & 0.43 & 0.07 & 1 & 0.23 \\
\hline Chilopoda & Scolopendromorpha & 0.00 & 1.58 & 40 & 0.88 \\
\hline Diplopoda & Spirobolida & 0.00 & 0.17 & 5 & 0.09 \\
\hline \multirow[t]{2}{*}{ Arachnida } & Acarina & 0.00 & 0.03 & 1 & 0.02 \\
\hline & Aranea & 7.39 & 9.99 & 166 & 8.84 \\
\hline Crustacea & Isopoda & 0.00 & 0.91 & 16 & 0.51 \\
\hline Gastropoda & Stylommatophora & 0.00 & 1.07 & 30 & 0.60 \\
\hline Reptilia & Squamata & 0.00 & 0.17 & 5 & 0.09 \\
\hline Unknown & & 0.00 & 1.27 & 25 & 0.71 \\
\hline
\end{tabular}

PianKa \& VitT, 2003). Prey such as millipedes (Diplopoda) are known to produce toxins, and it is suggested that actively foraging lizards can presumably detect the toxic compounds released by these prey and therefore avoid them, whereas sit-and-wait foragers generally do not (VITT \& COOPER, 1986). Seeing as J. swinhonis does feed on millipedes, this further supports the suggestion that this species utilizes a sit-and-wait foraging strategy.
Most of the prey items of the J. swinhonis from southwestern Taiwan belonged to orders described as prey of J. swinhonis in the studies done in other parts of Taiwan. Dietary studies from northern Taiwan (KuO et al., 2007) and Orchid Island (HuAnG, 2007) found that hymenopterans (primarily Formicidae) were the most frequently preyed upon items, and although these prey were not as large as some of the other common prey orders, either volumetrically or by mass, they still tended to have 
a high index of relative importance (IRI; Table 4). As in those studies, hymenopterans comprised a large part of the diet of J. swinhonis from southwestern Taiwan.

HUANG (2007) did not record isopterans in the diet of $J$. swinhonis from Orchid Island, while KUO et al. (2007) infrequently recorded isopterans in the diet of $J$. swinhonis from northern Taiwan. Although isopterans were the most numerous dietary items in the diet of $J$. swinhonis samples from Yunlin, it is highly unlikely that this is due to a regional dietary variation. Rather, the isopterans recorded were winged sexuals, which would illustrate the opportunistic feeding behaviour of J. swinhonis, and how these lizards make use of a temporarily available dietary resource. None of the J. swinhonis dietary studies exa- mined the seasonal utilization of prey or examined the diet of these lizards systematically for a whole year, and thus there is not enough information to comment on the seasonality of prey. However, seasonal differences could exist and deserve further empirical studies. It should also be noted that even though the diet of J. swinhonis consist primarily of numerous, relatively common, small prey, such as ants and lepidopteran larvae, these lizards may also eat relatively large prey (Fig. 2).

Since $J$. swinhonis usually perches a short distance above the ground on tree trunks and other objects, but forages readily on the ground (Jun-Yi \& KaU-HunG, 1982; KUO et al., 2007), it can be described as a trunkground species (WILLIAMS, 1972). This means that the exotic invasive lizard, A. sagrei, occu-

Table 4: Occurrence frequency $(\mathrm{F})$, mean percent weight $(\mathrm{W})$ or mean percent volume $(\mathrm{V})$, and index of relative importance (IRI) of each type of dietary item in male and female Japalura swinhonis from northern Taiwan (data retrieved from KUO et al., 2007) and in adult J. swinhonis from Orchid Island (data retrieved from HUANG, 2007). The IRI for the Orchid Island population is calculated following BJORNDAL et al. (1997) with data from the original publication. The IRI for the northern Taiwan population is retrieved from the original publication.

\begin{tabular}{|c|c|c|c|c|c|c|c|c|c|c|}
\hline \multirow{3}{*}{ Class } & \multirow{3}{*}{ Order } & \multicolumn{6}{|c|}{ Northern Taiwan } & \multirow{2}{*}{\multicolumn{3}{|c|}{$\begin{array}{l}\text { Orchid Island } \\
\qquad(\mathrm{N}=20)\end{array}$}} \\
\hline & & \multicolumn{3}{|c|}{ Males $(\mathrm{N}=29)$} & \multicolumn{3}{|c|}{ Females $(\mathrm{N}=27)$} & & & \\
\hline & & $\mathrm{F}$ & W & IRI & $\mathrm{F}$ & W & IRI & $\mathrm{F}$ & $\mathrm{V}$ & IRI \\
\hline \multirow[t]{9}{*}{ Insecta } & Coleoptera & 6 & 5.65 & 2.52 & 10 & 7.15 & 5.23 & 1 & 11.79 & 2.62 \\
\hline & Hemiptera & 5 & 6.92 & 2.57 & 7 & 5.75 & 2.94 & & & \\
\hline & Homoptera & 5 & 11.06 & 4.11 & 4 & 5.62 & 1.64 & 2 & 11.85 & 5.26 \\
\hline & Hymenoptera & 24 & 28.45 & 50.7 & 25 & 22.45 & 41.04 & 16 & 7.31 & 25.97 \\
\hline & Isoptera & 2 & 1.80 & 0.27 & 0 & 0 & 0 & & & \\
\hline & Lepidoptera & 15 & 32.17 & 35.83 & 15 & 38.55 & 42.29 & & & \\
\hline & Orthoptera & 4 & 3.04 & 0.9 & 6 & 0.54 & 0.24 & 5 & 55.05 & 61.11 \\
\hline & Psocoptera & 3 & 0 & 0 & 2 & 0 & 0 & & & \\
\hline & Insect larvae & & & & & & & 3 & 1.97 & 1.31 \\
\hline Chilopoda & Scolopendromorpha & 3 & 1.53 & 0.34 & 3 & 1.51 & 0.33 & 1 & 7.25 & 1.61 \\
\hline Diplopoda & Spirobolida & 2 & 0 & 0 & 2 & 4.02 & 0.59 & & & \\
\hline Arachnida & Aranea & 10 & 3.18 & 2.36 & 15 & 3.13 & 3.43 & 2 & 4.79 & 2.13 \\
\hline Crustacea & Isopoda & 2 & 0.77 & 0.11 & 5 & 1.35 & 0.49 & & & \\
\hline Gastropoda & Stylommatophora & 3 & 1.30 & 0.29 & 3 & 8.06 & 1.77 & & & \\
\hline
\end{tabular}



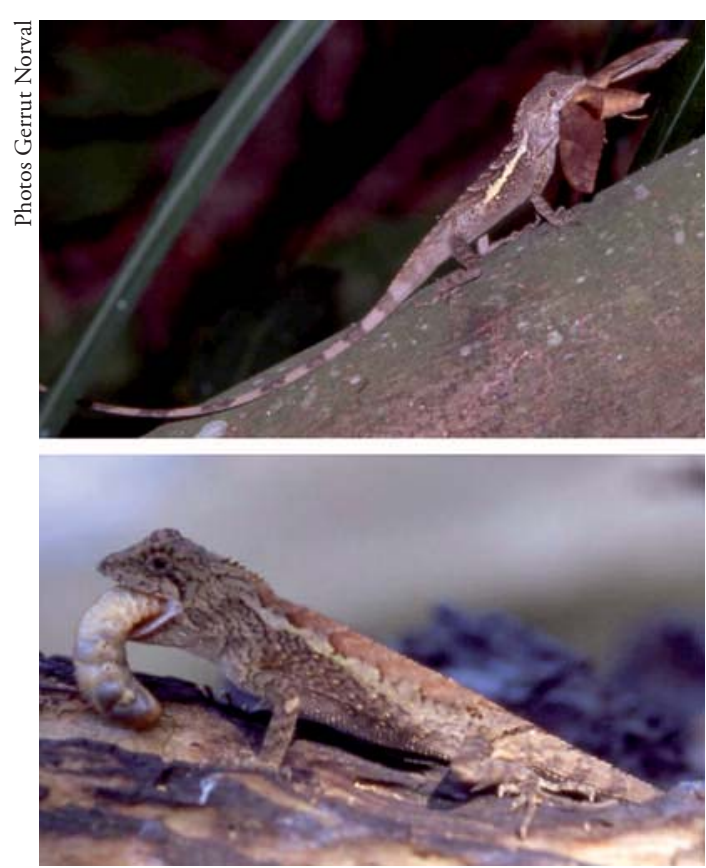

Figure 2: Japalura swinhonis feeding on large prey. (top) A male in Santzepu, Sheishan District, Chiayi County, southwestern Taiwan, preying on a relatively large moth (Sphingidae). (bottom) A female from the same area consuming a stag beetle (Lucanidae) grub.

pies the same niche as J. swinhonis, and both species have the same foraging mode. The Levin's measures also indicate that the niche breadth of $A$. sagrei is broader than that of $J$. swinhonis. From the results of this study it is also clear that in areas where these two lizard species are sympatric there is a substantial dietary niche overlap, and therefore competition for prey is very likely. However, J. swinhonis males and females have SVLs that range from 22 to $82 \mathrm{~mm}(\mathrm{~N}=104$; mean $\pm \mathrm{SD}=$ $70.5 \pm 8.4)$ and 22 to $74 \mathrm{~mm}(\mathrm{~N}=59$; mean $\pm \mathrm{SD}=58.2 \pm 13.9$ ) respectively (G. Norval, personal observation; from a sample of animals larger than what was used for the present study), and are thus substantially larger than $A$. sagrei from populations in Taiwan, where males and females have SVLs that range from 16 to $64 \mathrm{~mm}(\mathrm{~N}=522$; mean \pm $\mathrm{SD}=46.2 \pm 9.1)$ and 17 to $48 \mathrm{~mm}(\mathrm{~N}=538$; mean $\pm \mathrm{SD}=38.2 \pm 5.5$ ), respectively (G. Norval, personal observation). This means that adults of $J$. swinhonis should be able to feed on larger prey than $A$. sagrei. It is also worth pointing out that in interactions in the wild, $A$. sagrei usually gives way to $J$. swinhonis (G. Norval, personal observation). So, even though there is a substantial dietary overlap between these species, it is unlikely to have a negative effect on J. swinhonis.

Lister (1976) found that in the presence of competition from sympatric anole species, A. sagrei tends to occupy lower perches. However, in the presence of terrestrial predators, $A$. sagrei tends to be more arboreal (SCHOENER et al., 2002; Losos, 2009). Both the competition for prey and the microhabitat shift to higher perches result in reduced foraging opportunities and a subsequent reduction in body sizes of these lizards (LISTER, 1976; SCHOENER \& SCHOENER, 1978; SCHOENER et al., 2002; Losos, 2009). So, competition between $J$. swinhonis and $A$. sagrei, especially in habitats where terrestrial predators such as Eutropis longicaudata occur, could reduce the ability of $A$. sagrei to compete with other sympatric saurian species in Taiwan.

It must be noted that, through predation, A. sagrei impacts arthropod populations (SPILler \& SCHOENER, 1994; SCHOENER \& SPILlER, 1996; SCHOENER et al., 2002; HUANG et al., 2008a,b). Because sympatric J. swinhonis and $A$. sagrei prey on many of the same types of prey, it can be expected that they can thus exert substantial pressure on arthropods. How such combined pressures would affect arthropod communities warrants empirical studies. 
There does not seem to be an apparent decline in J. swinhonis or A. sagrei in areas where these lizards are sympatric (G. Norval, personal observation). In highly disturbed and open habitats, such as in $A$. catechu plantations, $A$. sagrei tends to be more abundant than J. swinhonis (HUANG et al., 2008a). However, in less disturbed areas, such as parks with large trees, even though $A$. sagrei is present, J. swinhonis tends to be more abundant (G. Norval, personal observation). Thus, the differences in the densities of these lizards most likely depend on the habitat structure. Japalura swinhonis is more shady-habitat tolerant than A. sagrei (HUANG et al., 2008a), which does not occur in closed habitats (Losos et al., 1993), so the re-establishment of large areas of broadleaf forests in disturbed lowland areas of Taiwan will contribute to the conservation of J. swinhonis and other native forest species. Such areas will also function as reservoirs of species like $J$. swinhonis that can compete with $A$. sagrei, as well as being barriers for its spread.

\section{Acknowledgement}

The authors thank Jin-Hsiang Wu for his assistance with the collection of lizards from Yunlin County. The research presented here adhered to the Guidelines for the Use of Live Amphibians and Reptiles in Field Research (SSAR, ASIH, and HL), and the legal requirements of Taiwan, R.O.C. Since A. sagrei is an exotic invasive species in Taiwan, which the authorities wishes to exterminate, and $J$. swinhonis is not listed as a protected species, and because the collection was not done within a National Park or other conservation area, no collection permit or other documentation was required.

\section{REFERENCES}

Bjorndal, K.A.; Bolten, A.B.; Lagueux, C.J. \& JACKSON, D.R. (1997). Dietary overlap in three sympatric congeneric freshwater turtles (Pseudemys) in Florida. Chelonian Conservation and Biology 2: 430-433.

Bulté, G.; Gravel, M.-A. \& BlouinDEMERS, G. (2008). Intersexual niche divergence in northern map turtles (Graptemys geographica): the roles of diet and habitat. Canadian Journal of Zoology 86: $1235-1243$.

CHANG, N.-C. (2007). [A new discovered alien lizard of Hualien - Anolis sagrei]. Quarterly of Natural Conservation 57: 3741. (in Chinese)

Chiu, P.-K.; Norval, G.; Chu, H.-P. \& MAO, J.-J. (2011). Two records of brown shrikes (Lanius cristatus Linnaeus, 1758) preying on brown anoles (Anolis sagrei Duméril \& Bibron, 1837) in Taiwan. Herpetology Notes 4: 87-89.

Dunham, A.E.; Grant, B.W. \& Overall, K.L. (1989). Interfaces between biophysical and physiological ecology and the population ecology of terrestrial vertebrate ectotherms. Physiological Zoology 62: 335-355.

Goodyear, S.E. \& PiankA, E.R. (2011). Spatial and temporal variation in diets of sympatric lizards (genus Ctenotus) in the Great Victoria Desert, Western Australia. Journal of Herpetology 45: 265-271.

Hawlena, D. \& Pérez-Mellado, V. (2009). Change your diet or die: predator-induced shifts in insectivorous lizard feeding ecology. Oecologia 161: 411-419.

Huang, S.-C.; Norval, G.; WeI, C.-S. \& Tso, I.-M. (2008a). Effects of the brown anole invasion and betelnut palm plan- 
ting on arthropod diversity in southern Taiwan. Zoological Science 25: 1121-1129. Huang, S.-C.; Norval, G. \& Tso, I.-M. (2008b). Predation by an exotic lizard, Anolis sagrei, alters the ant community structure in betelnut palm plantations in southern Taiwan. Ecological Entomology 33: 569-576. HUANG, W.-S. (2007). Ecology and reproductive patterns of the agamid lizard Japalura swinhonis on an East Asian island, with comments on the small clutch sizes of island lizards. Zoological Science 24: 181-188.

HueY, R.B. \& PiANKA, E.R. (1981). Ecological consequences of foraging mode. Ecology 62: 991-999.

Jun-Yi, L. \& KaU-Hung, L. (1982). Population ecology of the lizard Japalura swinhonis formosensis (Sauria: Agamidae) in Taiwan. Copeia 1982: 425-434.

KÖHLER, G. (2000). Reptilien und Amphibien Mittelamerikas. Band 1: Krokodile Schildkröten Echsen. Herpeton, Offenbach, Germany.

Krebs, C.J. (1999). Ecological Methodology, $2^{\text {nd }}$ ed. Addison Wesley Longman, Menlo Park, California, USA.

KuO, C.-Y.; LIN, Y.-S. \& LIN, Y.K. (2007).

Resource use and morphology of two sympatric Japalura lizards (Iguania: Agamidae). Journal of Herpetology 41: 713-723.

LEE, J.C. (2000). A Field Guide to the Amphibians and Reptiles of the Maya World. The Lowlands of Mexico, Northern Guatemala, and Belize. Cornell University Press, Ithaca, New York, USA.

LIsTER, B.C. (1976). The nature of niche expansion in West Indian Anolis lizards I: ecological consequences of reduced competition. Evolution 30: 659-676.

Losos, J.B. (2009). Lizards in an Evolutionary
Tree. Ecology and Adaptive Radiation of Anoles. University of California Press, Berkeley, California, USA.

Losos, J.B. \& SpILler, D.A. (1999). Differential colonization success and asymmetrical interactions between two lizard species. Ecology 80: 252-258.

Losos, J.B.; Marks, J.C. \& Schoener, T.W. (1993). Habitat use and ecological interaction of an introduced and a native species of Anolis lizard on Grand Cayman, with a review of the outcomes of anole introductions. Oecologia 95: 525-532.

NorVAL, G. \& MAO, J.-J. (2008). An instance of arboricolous predation by a mountain wolf snake (Lycodon ruhstrati ruhstrati [Fischer, 1886]) on a brown anole (Norops sagrei Duméril \& Bibron, 1837). Sauria 30: 59-62. Norval, G.; MaO, J.-J.; Chu, H.-P. \& CHEN, L.-C. (2002). A new record of an introduced species, the brown anole (Anolis sagrei) (Duméril \& Bibron, 1837), in Taiwan. Zoological Studies 41: 332-336. Norval, G.; MaO, J.-J. \& CHU, H.-P. (2004). Mabuya longicaudata (long-tailed skink). Predation. Herpetological Review 35: 393-394.

Norval, G.; Huang, S.-C. \& MaO, J.-J. (2007). Mountain wolf snake (Lycodon $r$. ruhstrati) predation on an exotic lizard, Anolis sagrei, in Chiayi County, Taiwan. Herpetological Bulletin 101: 13-17.

Norval, G.; MaO, J.-J.; Bursey, C.R. \& GoldberG, S.R. (2009). A deformed hind limb of an invasive free-living brown anole (Anolis sagrei Duméril \& Bibron, 1837) from Hualien City, Taiwan. Herpetology Notes 2: 219-221.

Norval, G.; HsiaO, W.-F.; Huang, S.-C. \& CHEN, C.-K. (2010). The diet of an intro- 
duced lizard species, the brown anole (Anolis sagrei), in Chiayi County, Taiwan. Russian Journal of Herpetology 17: 131-138. Norval, G.; ChIU, P.-K.; Chu, H.-P. \& MAO, J.-J. (2011). An instance of predation on a brown anole (Anolis sagrei Duméril \& Bibron, 1837) by a Malay night heron (Gorsachius melanolophus Swinhoe, 1865). Herpetology Notes 4: 5-7. Ortega-Rubio, A.; GonzÁleZ-Romero, A. \& Barbault, R. (1995). Food analysis and resource partitioning in a lizard guild of the Sonoran Desert, Mexico. Journal of Arid Environments 29: 367-382.

OTA, H. (1991). Taxonomic redefinition of Japalura swinhonis Günther (Agamidae: Squamata), with a description of a new subspecies of $J$. polygonata from Taiwan. Herpetologica 47: 280-294.

PIANKA, E.R. \& ViTT, L.J. (2003). Lizards: Windows to the Evolution of Diversity. University of California Press, Berkeley, California, USA.

RochA, C.F.D. \& ANjos, L.A. (2007). Feeding ecology of a nocturnal invasive alien lizard species, Hemidactylus mabouia Moreau de Jonnès, 1818 (Gekkonidae), living in an outcrop rocky area in southeastern Brazil. Brazilian Journal of Biology 67: 485-491.

Rodríguez, A.; Nogales, M.; Rumeu, B. \& RoDríguEZ, B. (2008). Temporal and spatial variation in the diet of the endemic lizard Gallotia galloti in an insular Mediterranean scrubland. Journal of Herpetology 42: 213-222.

SAlzBURG, M.A. (1984). Anolis sagrei and Anolis cristatellus in southern Florida: a case study in interspecific competition. Ecology 65: 14-19.

Schoener, T.W. \& Schoener, A. (1978). Estimating and interpreting body-size growth in some Anolis lizards. Copeia 1978: 390-405.

Schoener, T.W. \& SPILler, D.A. (1996).

Devastation of prey diversity by experimentally introduced predators in the field. Nature 381: 691-694.

Schoener, T.W.; Spiller, D.A. \& Losos, J.B. (2002). Predation on a common Anolis lizard: can the food-web effects of a devastating predator be reversed? Ecological Monographs 72: 383-407.

Schwartz, A. \& Henderson, R.W. (1991). Amphibians and Reptiles of the West Indies: Descriptions, Distributions, and Natural History. University Press of Florida, Gainesville, Florida, USA.

Spiller, D.A. \& Schoener, T.W. (1994). Effects of top and intermediate predators in a terrestrial food web. Ecology 75: 182-196. TOKARZ, R.R. \& BECK, JR., J.W. (1987). Behaviour of the suspected lizard competitors Anolis sagrei and Anolis carolinensis: an experimental test for behavioural interference. Animal Behaviour 35: 722-734.

Vieira, E.M. \& PorT, D. (2007). Niche overlap and resource partitioning between two sympatric fox species in southern Brazil. Journal of Zoology 272: 57-63.

ViTT, L.J. \& COOPER, JR., W.E. (1986). Foraging and diet of a diurnal predator (Eumeces laticeps) feeding on hidden prey. Journal of Herpetology 20: 408-415.

WiLliams, E.E. (1972). The origin of faunas. Evolution of lizard congeners in a complex island fauna: a trial analysis. Evolutionary Biology 6: 47-89.

ZuG, G.R.; VITT, L.J. \& CALDWELL, J.P. (2001). Herpetology. An Introductory Biology of Amphibians and Reptiles, $2^{\text {nd }} e d$. Academic Press, San Diego, California, USA. 